УДК 332.14:352

\title{
ВПЛИВ ОБ'ЄДНАНИХ ТЕРИТОРІАЛЬНИХ ГРОМАД НА ІНВЕСТИЦІЙНУ ПРИВАБЛИВІСТЬ РЕГІОНУ
}

\section{THE INFLUENCE OF UNITED TERRITORIAL COMMUNITIES ON THE INVESTMENT ATTRACTIVENESS OF THE REGION}

\author{
Білоус Світлана Петрівна \\ кандидат економічних наук, доцент, \\ Черкаський національний університет \\ імені Богдана Хмельницького \\ ORCID: https://orcid.org/0000-0002-0303-7453 \\ Степанець Іван Володимирович \\ здобувач наукового ступеня, \\ ПрАТ Вищий навчальний заклад \\ «Міжрегіональна Академія управління персоналом» \\ ORCID: https://orcid.org/0000-0002-8614-2186 \\ Belous Svetlana \\ Cherkasy National University named after B. Khmelnytsky \\ Stepanets Ivan \\ PJSC Higher Educational Institution \\ «Interregional Academy of Personnel Management»
}

\begin{abstract}
Стаття присвячена дослідженню впливу об'єднаних територіальних громад на інвестиційну привабливість регіону. Визначено, що питання впливу об'єднаних територіальних громад на розвиток регіону набуло в умовах активізації процесів децентралізації. Обґрунтовано, що сукупність усіх ресурсів утворює потенціал громади, який є певним «профрілем» ОТГ, який дозволяє інвестору прийняти рішення щодо доцільності інвестування, напрямів вкладання коштів. Авторами виокремлено п'ять груп фракторів, які фрормують інвестиційний клімат: рівень розвитку продуктивних сил та стан інвестиційного ринку; політична воля влади та правове поле держави; стан фрінансово-кредитної системи і діяльність фрінансових посередників; статус іноземного інвестора; інвестиційна активність населення. Обґрунтовано необхідність вдосконалення ключових принципів інвестиційної політики через створення ефективного правового поля, що регулює інвестиційну діяльність, макроекономічної та політичної стабільності, запровадження податкових та митних пільг, дотацій, субсидій, субвенцій і бюджетних позик на розвиток пріоритетних сорер галузей економіки.
\end{abstract}

Ключові слова: інвестиційна привабливість, регіон, об'єднані територіальні громади, інвестиційний паспорт, інституційне середовище, інвестиційна політика, механізм.

Статья посвящена исследованию влияния объединенных территориальных общин на инвестиционную привлекательность региона. Определено, что вопросы влияния объединенных территориальных общин на развитие региона приобрели в условиях активизации процессов децентрализации. Обосновано, что совокупность всех ресурсов образует потенциал общества, который является определенным «профилем» ОТО, который позволяет инвестору принять решение о целесообразности инвестирования, направлений вложения средств. Авторами выделены пять групп фракторов, которые фоормируют инвестиционный климат: уровень развития производительных сил и состояние инвестиционного рынка; политическая воля власти и правовое поле государства; состояние фринансово-кредитной системы и деятельность фринансовых посредников; статус иностранного инвестора; инвестиционная активность населения. Обоснована необходимость совершенствования ключевых принципов инвестиционной политики через создание эфрфективного правового поля, регулирующего инвестиционную деятельность, макроэкономической и политической стабильности, введение налоговых и таможенных льгот, дотаций, субсидий, субвенций и бюджетных ссуд на развитие приоритетных сорер отраслей экономики.

Ключевые слова: инвестиционная привлекательность регион, объединенные территориальные общины, инвестиционный паспорт, институциональная среда, инвестиционная политика, механизм. 
The article is devoted to the study of the influence of the united territorial communities on the investment attractiveness of the region. It is determined that the issue of the influence of united territorial communities on the development of the region acquired in the conditions of intensification of decentralization processes, which allows to determine the place and role of certain units in the development of the regional system. It is important to take into account the specific characteristics of the united territorial communities, such as dominance in the structure of a particular industry or sector of the economy, the peculiarities of the culture of economic management and their values. It is substantiated that the totality of all resources forms the potential of the community, which is a certain "profile" of UTC, which allows the investor to make decisions about the feasibility of investing, areas of investment. The key criterion is not the amount of resources, but the efficiency of their use within the territorial entity, which forms the investment attractiveness of both individual UTC and affects the attraction of funds to the region. Investment attractiveness is directly related to the investment climate, for which there are different methods for assessing. The authors singled out five groups of factors that shape the investment climate: the level of development of productive forces and the state of the investment market; political will of the government and the legal field of the state; the state of the financial and credit system and the activities of financial intermediaries; foreign investor status; investment activity of the population. Based on the analysis of these factors, four types of environments have been formed, which are in fact components of the investment climate: political and legal environment; socio-cultural environment; economic environment; institutional and infrastructural environment. The need to improve the key principles of investment policy through the creation of an effective legal framework governing investment activities, macroeconomic and political stability, the introduction of tax and customs benefits, subsidies, subsidies, subventions and budget loans for the development of priority sectors of the economy.

Keywords: investment attractiveness, region, united territorial communities, investment passport, institutional environment, investment policy, mechanism.

Постановка проблеми. На сучасному етапі розвитку економіки регіону об'єднані територіальні громади (ОТГ) відграють провідну роль у забезпеченні його фуункціонування та життєдіяльності. Реалізація ресрорми адміністративно-територіального поділу та її практичне втілення визначають необхідність аналізу розвитку окремих територіальних одиниць, ефективність фрункціонування яких проектується на показники регіонального розвитку в цілому. Сукупність одиниць утворює територіальну систему, яка характеризується взаємодією її складових елементів. Тобто громада $є$ своєрідним центром життєдіяльності людини, де концентруються економічні, соціальні, політичні, екологічні та господарські процеси, і навколо якого об'єднуються периферійні територіальні одиниці.

У зв'язку із цим постає питання забезпечення повноцінного розвитку центру, який $€$ «живильним соком, джерелом енергії» для інших територіальних одиниць та регіону загалом. При цьому центр визначається не за географрічно-просторовою ознакою, а значущістю для розвитку регіону та впливом на його фрункціонування, яка характеризується наявним природно-ресурсним потенціалом, кількістю населення та рівнем життя, збалансованістю ринку праці, структурою економіки, що визначає елементи «інвестиційного паспорту. Окремі територіальні одиниці характеризуються незначним внеском порівняно 3 об'єднаними територіальними громадами в загальний регіональний розвиток.
Особливої актуальності питання розвитку впливу об'єднаних територіальних громад на розвиток регіону набуло в умовах активізації процесів децентралізації, яка дозволяє визначити місце і роль певних одиниць у розвитку регіональної системи. При цьому важливим $€$ врахування специфрічних характеристик об'єднаних територіальних громад, таких як домінування у структурі певної галузі або сектору економіки, особливості культури господарювання населення та їх ціннісні орієнтації. Це дозволяє максимально використати потенційні можливості територіальної одиниці, і відповідно, підвищити рівень розвитку регіону в цілому.

Аналіз попередніх досліджень. Питання децентралізації, фрормування та розвитку об'єднаних територіальних громад ґрунтовно досліджені в працях іноземних та українських учених. Серед зарубіжних вчених необхідно виокремити Б. Дрейорюса [1]. Питання формування та фрункціонування та розвитку територіальних громад в Україні досліджували вітчизняні науковці, зокрема В. Бабаєв, І. Дробот, Ю. Куц, Ю. Молодожен, В. Наконечний та інші [2-9]. Серед українських науковців на проблематиці впливу ОТГ на розвиток регіону зосереджують увагу І. Бланк [10], В. Захожай, М. Кіт [11], М. Кизим [12], С. Петровська [13], Сторонянська І.3. [14], Т. Уманець [15], Ушаков В.В. [16] та інші.

Формування цілей статті. Визначити та проаналізувати вплив об'єднаних територіальних громад як складових регіону на його інвестиційну привабливість. 
Незважаючи на значну кількість наукових результатів потребує більш глибокого аналізу дослідження впливу ОТГ на інвестиційну привабливість регіону як системи.

Виклад основного матеріалу дослідження. Реалії сьогодення переконливо доводять, що відсутність належної уваги до дослідження особливостей функціонування і розвитку ОТГ призводить до уповільнення регіонального розвитку та зниження рівні інвестиційної привабливості.

На сучасному етапі в національній економіці відбувається активізація процесів децентралізації, невід'ємною частиною якої $€$ формування таких територіальних утворень, які б мали високий рівень самодостатності та забезпечували есрективність фрункціонування національної економіки за рахунок раціонального використання власних ресурсів. Зауважимо, що фрункціонування кожної об'єднаної територіальної громади зорієнтоване на досягнення кінцевих результатів та цілей необхідно розглядати з урахуванням синхронізації головних елементів єдиної системи. Громада як складне соціально-економічне утворення характеризується певним впорядкуванням складових частин, тобто має визначену структуру.

Підкреслимо, що у національній економіці утворення об'єднаних територіальних громад $€$ засобом реалізації загальнодержавної політики децентралізації, метою якої $є$ підвищення ефрективності фрункціонування національної економіки та зростання рівня життя населення шляхом перерозподілу повноважень, фрінансових коштів та залучення громадян до управління.

Зауважимо, що важливим питанням для срункціонування і розвитку об'єднаних територіальних громад $€$ не лише визначення певного набору елементів, а й визначення узгодженості між ними, що безпосередньо впливає на залучення інвестиційних ресурсів на рівні громади зокрема та регіону загалом. При цьому, слід підкреслити, необхідність існування прямого зв'язку між рівнем взаємодії між елементами структури громади та її розвитком: чим більш узгодженим $\epsilon$ фрункціонування складових громади, тим більша ймовірність успішності її розвитку, і, відповідно, гармонізації регіональної системи.

В умовах активізації процесів децентралізації перед національною економікою постало завдання утворення територіальних об'єднань, які б ефрективно фрункціонували і всебічно розвивалися, а також залучали інвестиційні ресурси до регіонів.
Враховуючи складність умов та середовище, в якому потрібно буде фрункціонувати та успішно розвиватися об'єднаним територіальним громадам, необхідним є синтез, що дозволяє врахувати не тільки унікальність окремих територій, їх людські, земельні та капітальні ресурси, але й визначити перспективи на майбутнє.

Сукупність усіх ресурсів утворює потенціал громади, який є певним «профрілем» ОТГ, який дозволяє інвестору прийняти рішення щодо доцільності інвестування, напрямів вкладання коштів. При цьому в якості ключового критерію визначено не обсяг ресурсів, а есрективність їх використання в межах територіального утворення. Усе вищезазначене срормує інвестиційну привабливість як окремої ОТГ, так і впливає на залучення коштів до регіону.

Інвестиційна привабливість безпосередньо пов'язана з інвестиційним кліматом, для оцінки якого існують різні методики. У окремих методиках оцінки кількість показників інвестиційного клімату, які описують характеристики інвестицій, значно змінюється і може коливатися від десяти до ста та більше ознак. Зауважимо, що можна здійснити типологізацію чинників, котрі визначають особливості середовища, яке $€$ невід'ємною складовою інвестиційного клімату: політико-правове середовище; соціально-культурне середовище; економічне середовище; інституціонально-інфраструктурне середовище.

Перелік основних узагальнених показників, що фрормують рівень розвитку відповідного середовища інвестиційного клімату наведено на рис. 1.

В умовах мінливого та динамічного зовнішнього середовища фрактори, що формують інвестиційний клімат постійно змінюються, отже потребують постійного впливу. Покращити інвестиційний клімат країни можливо за рахунок різноманітних заходів, зокрема через забезпечення чіткого правового поля, що регулює інвестиційну діяльність, макроекономічної та політичної стабільності, запровадження податкових та митних пільг, дотацій, субсидій, субвенцій і бюджетних позик на розвиток пріоритетних сорер галузей економіки, подолання бюрократичних бар'єрів, корупції, забезпечення правового захисту інвестицій, покращення інсрормаційного забезпечення та інвестиційної інфрраструктури (табл. 1).

Поліпшення інвестиційного клімату можливе через ефективну політику зі зниження інфрляції та інфрляційних очікувань, а також врегулювання проблем державного боргу, 


\begin{tabular}{|c|c|}
\hline Політико-правове середовище & Економічне середовище \\
\hline $\begin{array}{l}\text { 1. Стабільність законодавчої бази з } \\
\text { питань регулювання інвестиційної, } \\
\text { податкової та підприємницької } \\
\text { діяльності. } \\
\text { 2. Стабільність політичного } \\
\text { середовища. } \\
\text { 3. Механізм гарантій і захисту } \\
\text { інвестицій. } \\
\text { 4. Відносини власності у держави. } \\
\text { 5. Наявність торгівельних бар'єрів. } \\
\text { 6. Наявність бюрократичних бар'єрів і } \\
\text { корупції. }\end{array}$ & $\begin{array}{l}\text { 1. Макроекономічне становище країни. } \\
\text { 2. Стан та структура виробництва. } \\
\text { 3. Стан та структура факторів (ресурсів) } \\
\text { виробництва. } \\
\text { 4. Стан розвитку грошово-кредитної } \\
\text { системи. } \\
\text { 5. Стан розвитку бюджетно-податкової } \\
\text { системи. } \\
\text { 6. Наявність вільних економічних та } \\
\text { офшорних зон. } \\
\text { 7. Розмір безробіття та заробітної плати. } \\
\text { 8. Стан ринку інвестицій (наявність } \\
\text { інших інвесторів та їх досвід } \\
\text { інвестицій). }\end{array}$ \\
\hline$\downarrow$ & $\downarrow$ \\
\hline \multicolumn{2}{|c|}{ Інвестиційний клімат } \\
\hline$\uparrow$ & $\uparrow$ \\
\hline Соціально-культурне середовище & $\begin{array}{c}\text { Інституціонально-інфраструктурне } \\
\text { середовище }\end{array}$ \\
\hline $\begin{array}{l}\text { 1. Демографічна ситуація та структура } \\
\text { ринку робочої сили. } \\
\text { 2. Соціальна структура суспільства. } \\
\text { 3. Виробнича та матеріальна культура. } \\
\text { 4. Рівень освіти. } \\
\text { 5. Рівень злочинності. }\end{array}$ & $\begin{array}{l}\text { 1. Близькість до світових ринків, митних } \\
\text { переходів } \\
\text { 2. Стан та структура ринку банківських, } \\
\text { кредитних, аудиторських, страхових } \\
\text { послуг, фондового ринку. } \\
\text { 3. Наявність розвинутих транспортних, } \\
\text { енергетичних комунікацій, систем } \\
\text { зв’язку, водопостачання тощо. }\end{array}$ \\
\hline
\end{tabular}

Рис. 1. Складові інвестиційного клімату - детермінанти інвестиційної привабливості

забезпечення процедур захисту прав власників та інвесторів. Тобто створення таких сприятливих умов, при яких підвищується міжнародний імідж країни та зацікавленість інвестора працювати на території країни.

Таким чином, враховуючи низький рівень інвестиційної привабливості, виникає необхідність визначення дієвого інструментарію щодо залучення міжнародних інвесторів до розбудови економічного середовища та створення сприятливого інвестиційного клімату. Враховуючи досвід економічно розвинених країн, серед першочергових тактичних заходів можна виокремити такі:

- скорочення впливу держави на процеси міжнародного інвестування;

- спрощення системи адміністрування податків та зменшення їх відсоткових ставок;

- стабілізації економічних та політичних процесів;
- удосконалення нормативно-правової бази щодо регулювання діяльності міжнародних інвесторів на національному ринку.

За умови використання цих тактичних заходів країна підвищує рівень довіри міжнародних інвесторів, впевненість в правильності вибору країни, в яку вкладається капітал, а це в свою чергу формує позитивний імідж держави як надійного партнера.

Доцільно відзначити, що лібералізація та відкритість внутрішнього ринку негативно впливають на економічну ситуацію, оскільки в таких умовах країна переважно імпортує готові вироби, а експортує лише сировину. Тому, країнам за таких умов необхідно проводити політику імпортозаміщення шляхом підтримки національних товаровиробників унаслідок спрямування інвестиційного ресурсу для впровадження інноваційних технологій у виробництво та політику розвитку експорт- 
Таблиця 2

Механізм впливу на інвестиційний клімат

\begin{tabular}{|c|c|c|c|c|}
\hline $\begin{array}{c}\text { Забезпечення чіткого } \\
\text { правового поля інвестиційної } \\
\text { діяльності }\end{array}$ & & $\begin{array}{c}\text { Подолання } \\
\text { бюрократичних } \\
\text { бар'єрів та корупції }\end{array}$ & & $\begin{array}{c}\text { Запровадження } \\
\text { податкових та митних } \\
\text { пільг } \\
\end{array}$ \\
\hline & $\pi$ & $\uparrow$ & $\pi$ & \\
\hline \multirow[t]{2}{*}{ Інфрормаційне забезпечення } & $\leftarrow$ & $\begin{array}{c}\text { Механізм впливу } \\
\text { на інвестиційний клімат }\end{array}$ & $\rightarrow$ & Захист інфрормації \\
\hline & $k$ & $\downarrow$ & $y$ & \\
\hline $\begin{array}{c}\text { Дотації, субсидії, } \\
\text { бюджетні позики на розвиток } \\
\text { пріоритетних сорер та галузей }\end{array}$ & & $\begin{array}{c}\text { Макроекономічна } \\
\text { та політична стабільність }\end{array}$ & & $\begin{array}{c}\text { Розвиток інвестиційної } \\
\text { інфрраструктури }\end{array}$ \\
\hline
\end{tabular}

ного потенціалу високотехнологічних товарів через підтримку вітчизняних експортерів на світових ринках.

Зауважимо, що особливістю інвестиційних процесів $€$ усвідомлення того, що кінцевим результатом інвестування має бути досягнення високого рівня економічного добробуту, якості життя, поліпшення умов праці та розвиток регіону, об'єднаних територіальних громад та окремої людини. Адже, інвестиції можуть бути успішними та ефективними лише тоді, коли в Україні буде реалізовано принцип об'єднання свободи ведення бізнесу й ефективної державної політики. А це потребує зміни системи і людей. Оскільки саме виважена державна політика здатна забезпечити населення робочими місцями та необхідним рівнем життя.

Висновки. На основі проведеного дослідження можна зробити висновок, що на сучас- ному етапі розвитку суспільних відносин характерним $€$ активізація процесів децентралізації. У результаті формування територіальних громад, які $€$ спільнотою громадян України, котрі компактно проживають на міській чи сільській території, мають колективні інтереси і визначений законом правовий статус. На відміну від простої територіальної одиниці, поселення, яке має статус територіальної громади, наділяється певними правами. У першу чергу, це право на самоврядування.

Об'єднані територіальні громади (ОТГ) як елементи регіональної системи є дієвим способом залучення інвестицій за рахунок високої ефрективності управління інвестиційними ресурсами. Завдяки громадам забезпечується підвищення рівня зацікавленості інвесторів вкладати кошти в розвиток громади, i, відповідно, тим самим формує інвестиційну привабливість регіону.

\section{СПИСОК ВИКОРИСТАНИХ ДЖЕРЕЛ:}

1. Дрейфюс Б. Довідник територіальних громад / пер. 3 фр. за виданням Vademecum des collectivités locales et territoriales. Réforme de la TP. 9e édition. 06.2010.

2. Залуцький І., Брусак Р., Шевчук Б. та ін. Основи сталого розвитку територіальної громади : навчальний посібник. Київ : НАДУ, 2008. 64 с.

3. Безуглий О. Світовий досвід організації сталого розвитку територіальної громади. Теорія та практика державного управління : зб. наук. пр. Вип. 3(15). Харків : Магістр, 2006. С. 153-158.

4. Безуглий О. Територіальна громада в Україні: напрями та чинники сталого розвитку : авторефр. дис. ... канд. наук з держ. упр. : спец. 25.00.04 «Місцеве самоврядування». Харків, 2009. 17 с.

5. Бабаєв В. Управління великим містом: теоретичні і прикладні аспекти : монограсрія. Харків : Харків. нац. акад. міськ. госп-ва, 2010. 306 с.

6. Дробот І. Гарантування місцевого самоврядування в Україні: теоретико-методологічний аспект : монографрія. Львів : ЛРІДУ НАДУ, 2010. 312 с.

7. Куц Ю., Мамонова В., Чаплигін О. та ін. Сталий розвиток територіальної громади: управлінський аспект : монограсрія / за заг. ред. Ю. Куца, В. Мамонової. Харків : Магістр, 2008. 236 с.

8. Молодожен Ю. Самодостатність територіальних громад: системний підхід : монограсрія. Одеса : ОРІдУ НАДУ, 2010. $370 \mathrm{c}$.

9. Наконечний В. Управління містом: теоретико-методологічний вимір : монографрія. Харків : Цифррова друкарня, 2010. 263 с.

10. Бланк И.А. Инвестиционный менеджмент. Киев : Эльга-Н, Ника-Центр, 2001. 448 с. 
11. Захожай В., Кіт М. Статистика інвестиційної діяльності. URL: http://personal.in.ua

12. Кизим М.О., Кононова Є.Ю. Моделювання стратегії інвестиційної діяльності Харківського регіону. Фінанси України. 2002. № 10. С. 22-28.

13.Петровська С.А. Оцінка інвестиційної привабливості регіону: порівняльний пофакторний аналіз. Механізм регулювання економіки. 2012. № 2. С. 90-97.

14. Сторонянська І.3. Теорія та практика регіонального розвитку : колективна монографія. Дніпро : Герда, 2016. 584 C.

15.Уманець Т.В. Оцінка інвестиційної привабливості регіону за допомогою інтегральних індексів. URL: dspace.nbuv.gov.ua.

16. Ушаков В.В. Сутність понять «інвестиційна привабливість регіону» та «інвестиційний клімат в регіоні» та фрактори, що їх обумовлюють. URL: http://lubbook.net/book_431_glava_1_Tema_1

\section{REFERENCES:}

1. Dreyfus B. (2010) Handbook of territorial communities / trans. with fr. according to the edition of the Vademecum des collectivités local and territorial. TP reform. 9th edition.

2. Zalutsky I., Brusak R., Shevchuk B. and others (2008) Fundamentals of sustainable development of the territorial community: a textbook. Kyiv: NAPA.

3. Bezugly O. (2006) World experience of organizing sustainable development of the territorial community. Theory and practice of public administration: coll. science. etc., vol. 3(15). Kharkiv: Magistr.

4. Bezugly O. (2009) Territorial community in Ukraine: directions and factors of sustainable development: author's ref. dis. ... cand. sciences of the state.: 25.00 .04 "Local self-government". Kharkiv.

5. Babayev V. (2010) Management of a large city: theoretical and applied aspects: a monograph. Kharkiv: Kharkiv. nat. acad. city hosp-va.

6. Drobot I. (2010) Guarantee of local self-government in Ukraine: theoretical and methodological aspect: monograph. Lviv: LRIDU NADU.

7. Kuts Y., Mamonova V., Chaplygin O. and others (2008) Sustainable development of the territorial community: management aspect: monograph / for general. ed. Yu. Kuts, V. Mamonova. Kharkiv: Master.

8. Molodozhen Y. (2010) Self-sufficiency of territorial communities: a systematic approach: a monograph. Odessa: ORIDU NADU.

9. Nakonechny V. (2010) City management: theoretical and methodological dimension: monograph. Kharkiv Digital printing house.

10. Blank I.A. (2001) Investment Management: Training Course. Kyiv: Elga-N Nick's Center.

11. Zahozhaj V., Kit M. (2009) Statistics of investment activity. Available at: http://personal.in.ua

12. Kyzym M.O., Kononova Ye.Yu. (2002) Simulation investment strategy for Kharkov region. Finansy Ukrayiny, no. 10 , pp. $22-28$.

13. Petrovska S.A. (2012) Evaluation of investment attractiveness of the region: comparative factor analysis. Mehanizm regulyuvannya ekonomiky, no. 2, pp. 90-97.

14. Storonyanska I.Z. (2016) The theory and practice of regional development. Dnipro: Gerda.

15. Umanecz T.V. (2006) Evaluation of investment attractiveness of the region by means of integral indices. Available at: www.dspace.nbuv.gov.ua

16. Ushakov V.V. (2002) The essence of the concept of "investment attractiveness of the region" and "investment climate in the region" and the factors that cause them. Available at: www.lubbook.net/book_431_glava_1_Tema_1._html 